\title{
MOTINŲ VIDINĖS DARNOS IR KŪDIKIŲ MOTORINĖS RAIDOS SUBJEKTYVAUS VERTINIMO SĄSAJOS
}

\author{
Viktorija Sytnikova ${ }^{1}$, Veslava Radzevič ${ }^{1,2}$, Lina Budrienè $\dot{\mathbf{1}}^{1,2}$, \\ Juozas Raistenskis ${ }^{1,2}$, Vilma Dudoniené ${ }^{3}$ \\ Vilniaus Universitetas ${ }^{1}$ \\ Viešosios įstaigos Vilniaus universiteto ligoninès \\ Santaros kliniku filialo Vaiku ligoniné ${ }^{2}$
}

Lietuvos sporto universitetas ${ }^{3}$

\section{SANTRAUKA}

Tyrimo pagrindimas. Depresijos simptomų turinčios moterys mažiau domisi kūdikio raida, todèl turi mažiau žinių, nemoka tinkamai įvertinti raidos etapų, ir tai gali turèti įtakos motinos požiūriui i kūdikị, jo poreikių supratimui bei tenkinimui. Prastas vidinès darnos jausmas yra siejamas su didesniu stresu ir yra vienas svarbiausių depresijos rizikos veiksnių. Todèl negalima atmesti galimybès, kad vidinès darnos jausmas, turėdamas stiprią ịtaką motinų psichologinei sveikatai, gali turèti įtakos ir kūdikio raidai.

Tikslas - nustatyti sąsajas tarp motinų vidinès darnos lygio, motinų darnos su kūdikiu ir kūdikių motorinès raidos subjektyvaus vertinimo.

Metodai. Apklausoje dalyvavo 41 motina. Buvo naudojami penki klausimynai: sociodemografinių klausimų anketa; ,Vidinès darnos“ ir „Vidinès darnos su kūdikiu“ klausimynai, skirti įvertinti motinų vidinę darną, jos darną su kūdikiu; motinų kasdienio streso vertinimo,,Kasdienių rūpesčių skalë“; taip pat buvo modifikuota ị klausimyną Alberta kūdikių motorinès raidos skalè tuo tikslu, kad motinos galètu pačios įvertinti savo kūdikio motorinị vystymąsi.

Rezultatai. Motinoms, patiriančioms stiprų stresą, vidinès darnos balų vidurkis $(44,9 \pm 7,89)$ buvo statistiškai reikšmingai žemesnis, lyginant su motinomis, kurios stipraus streso nepatiria $(49,9 \pm 4,61)$. Nustatytas stiprus koreliacinis ryšys tarp motinų vidinès darnos ir darnos su kūdikiu $(\mathrm{r}=0,72 ; \mathrm{p}=0,003)$. Motinų subjektyvus jų kūdikių motorinès raidos vertinimas nepriklausè nuo motinų vidinès darnos balo $(\mathrm{r}=0,13 ; \mathrm{p}>0,05)$. Taip pat kūdikių motorinei raidai neturejo įtakos motinų vidinè darna $(\mathrm{r}=0,03 ; \mathrm{p}>0,05)$.

Išvada. Stiprios vidinès darnos motinos pasižymi ir stipria darna su kūdikiu. Subjektyvus kūdikių motorinès raidos vertinimas nepriklausè nuo motinų vidinès darnos lygio.

Raktažodžiai: vidinè darna, darna su kūdikiu, pogimdyvinè depresija, motorinè raida.

\section{IVADAS}

Kūdikystė yra intensyviausio mokymosi laikotarpis. Kiekvieną dieną kūdikis atranda naujus judesius, garsus, tobulina motorinius ir komunikacinius igūdžius. Motorinès raidos išsivystymo lygio atitikimas jo chronologiniam amžiui yra svarbiausias rodiklis, parodantis vaiko sveikatą, todèl sveikatos priežiūros specialis-

Copyright (C) 2020 Viktorija Sytnikova, Veslava Radzevič, Lina Budrienė, Juozas Raistenskis, Vilma Dudonienè. Published by Lithuanian Sports University.

This is an Open Access article distributed under the terms of the Creative Commons Attribution 4.0 International License, which permits unrestricted use, distribution, and reproduction in any medium, provided the original author and source are credited. 
tams būtina žinoti normalios motorinès raidos vystymosi etapus. Bet koks motorinès funkcijos vèlavimas gali neigiamai paveikti tolesnę vaiko raidą. Siekiant sumažinti motorinès raidos sutrikimų atsiradimo riziką, svarbu nustatyti motorinę raidą lemiančius veiksnius (Soares et al., 2018).

Vaiko motorinè raida priklauso nuo daugelio veiksnių: paveldimumo, vaiko sveikatos, ekonominių sąlygų, socialinės aplinkos, tėvų dėmesio, jų gebejjimo patenkinti svarbiausius fiziologinius ir emocinius vaiko poreikius, taip pat nuo pačiu tèvų fizinès ir psichologinès sveikatos (Kerstis et al., 2013). Sutrikusi motinos psichikos sveikata laikotarpiu po gimdymo yra laikoma vienu pagrindiniu motorinès raidos sutrikimų rizikos veiksniu, kuris neigiamai paveikia ankstyvą motinos ir kūdikio prieraišumo formavimąsi bei tolesnę kūdikio raidą (Radzevič ir kt., 2019). Dažniausias pogimdyvinis psichikos sveikatos sutrikimas, pasireiškiantis pirmaisiais metais po gimdymo, yra pogimdyvinė depresija (Sekizuka et al., 2006; Stewart, Vigod, 2019). Nustatyta, kad vaikai, kuriuos augina tėvai, turintys psichikos sveikatos sutrikimų, gauna mažiau dèmesio, tèvai mažiau reaguoja ị jų signalus, vaikai būna mažiau socializuoti, atsilieka jų kognityvinis ir motorinis vystymasis, todèl tèvų atsparumas stresui, jų psichologinè ir fizinè sveikata yra labai svarbi sékmingai vaiko raidai (Kerstis et al., 2013).

Viena iš psichologinès sveikatos sudedamujų dalių yra vidinè darna. Vidinė darna apibrěžiama kaip gebejimas matyti pasauli valdomą, suprantamą ir prasmingą (Mittelmark et al., 2017; Bauer et al., 2020). Nustatyta, kad moterys, kurias palaiko jų sutuoktiniai ir artimieji, yra fiziškai aktyvesnès, sveikiau maitinasi ir būna mažiau nerimastingos, taip pat jų vidinès darnos lygis būna aukštesnis, o žmogui, turinčiam aukštą vidinès darnos lygị, būna lengviau išgyventi stresines situacijas (del-Pino-Casado et al., 2019). Tuo tarpu motinos, turinčios žemą vidinės darnos lygị, turi didesnę riziką sirgti depresija (Hildingsson, 2017). Nuo vidinès darnos lygio priklauso vaiko ir motinos prieraišumo formavimasis ankstyvoje kūdikystejje. Remiantis šiais moksliniais pastebejjimais yra pagrindo manyti, kad motinos vidinès darnos lygis gali turèti ịtakos ir vaiko motoriniam vystymuisi, tačiau mokslinèje literatūroje iki šiol didžiausias dėmesys skiriamas motinų vidinès darnos bei jai įtaką darančių veiksnių analizavimui ir mažai nagrinejjama motinų darnos su kūdikiu problematika. Be to, nepavyko rasti mokslinių studijų, nagrinejjančių motinų vidinès darnos ir kūdikių motorinès raidos sąsajas. Todèl šio tyrimo esminis tikslas buvo nustatyti sąsajas tarp motinų vidinès darnos lygio ir kūdikių motorinès raidos subjektyvaus vertinimo.

\section{METODAI}

Tiriamieji. Dalyvauti tyrime buvo pakviestos motinos, pagimdžiusios išnešiotus ir sveikus kūdikius, neturinčius genetinių, raidos ar kitų diagnozuotų sveikatos 
sutrikimų. Kūdikių amžius neturèjo viršyti 12 mėnesių. Iš viso tyrime dalyvavo 41 motina.

Tyrimo organizavimas. Gavus sutikimą dalyvauti tyrime, motinoms buvo pateiktos anketos. Tyrimas buvo pradètas asmens sveikatos priežiūros įstaigoje, toliau tęstas nuotoliniu būdu naudojant Microsoft Forms programą. Kiekvienai motinai buvo paaiškinta tyrimo svarba, reikšmè ir tikslas, garantuotas tyrimo anonimiškumas ir konfidencialumas.

\section{Tyrimo metodai}

Tyrimas buvo vykdomas naudojant penkis klausimynus:

1. Bendrujų duomenu klausimynas. Buvo renkami motinų sociodemografiniai duomenys (amžius, išsilavinimas, gyvenamoji vieta, šeiminè padètis), informacija apie kūdikị (lytis, amžius); subjektyvūs klausimai (kaip tiriamoji prièmė žinią apie nèštumą, ar kūdikis buvo planuotas); informacija apie tai, kaip gimè kūdikis (ar gimdymo metu buvo komplikacijų; ar buvo atliktas cezario pjūvis).

2. A. Antonovskio vidinès darnos skale (Eriksson, Lindström, 2005). Ją sudaro 13 punktų, aprašančių ịvairias gyvenimo situacijas arba jausmus. Tiriamosios turèjo pasirinkti tinkamiausią variantą, tiksliausiai aprašantị, kaip dažnai aprašytos situacijos įvyksta tiriamųų gyvenime (labai dažnai, dažnai, kartais, retai, niekada). Kiekvienas atsakymas buvo koduojamas nuo 1 iki 5, bendras balų skaičius galèjo svyruoti nuo 13 iki 65 balų. Aukštesnis balų skaičius rodo geresnę vidinę darną.

3. Modifikuota vidinés darnos skalè. Ji parodo motinos darną su kūdikiu (Markūnienè, 2003). Motinos ir kūdikio darnos duomenys buvo vertinami surinktų balų suma. Didesnis balų skaičius rodè geresnę motinos ir kūdikio darną.

4. Motinos kasdieniu rūpesčiu klausimynas (Crnic, Greenberg, 1990). Jis sudarytas iš dviejų dalių. Pirmoje dalyje minimi su vaiko priežiūra susiję rūpesčiai. Aprašomi kasdieniai įvykiai šeimoje, tokie kaip sunkumai laiku paruošti kūdikị išvykai ir t. t. Antroje dalyje išvardyti kiti, ne su kūdikio priežiūra ir šeima susiję rūpesčiai - tokie kaip eismo problemos, sunkumai apsiperkant ir pan. 5 balų skalèje motinos vertino, kiek jas erzina minèti ịvykiai pradedant 1 balu - „Nẻ kiek“, baigiant 5 balais - „Labai stipriai“. Gautas balų skaičius parodo motinų streso lygi.

5. Alberta küdikiu motorinès raidos skale (AKMRS). Tai skalè (Piper et al., 1992), skirta įvertinti kūdikio nuo gimimo iki 18 mėnesių amžiaus motorinį vystymąsi. Skalè padeda įvertinti, atpažinti ir atrasti psichomotorinès raidos sutrikimus ar nukrypimus nuo normos. Remiantis šia skale buvo parengta anketa, sudaryta iš 30 klausimų. Pradžioje motinos turejjo atsakyti, ar, jų manymu, kūdikis atlieka visas užduotis, kurias turètų atlikti jo amžiaus kūdikiai, bei pakomentuoti savo atsakymą. Vèliau mamoms buvo pateikta išsamesnè anketa su teiginiais, kur kiekvienas teiginys apibūdino tam tikrą vaiko motorinės raidos etapą, o mamos turèjo 
pažymèti, ar jų kūdikis atlieka arba anksčiau atliko klausimyne aprašytus veiksmus. Kiekvieną teiginị motinos galèjo papildomai pakomentuoti (pvz., nurodyti, kiek laiko kūdikis praleidžia gulèdamas ant pilvo, arba paminèti, kad kūdikis jau žengia savarankiškai, tačiau labiau mėgsta ropoti ir pan.). Atsižvelgiant į anketos atsakymus bei motinų komentarus, kiekvieno kūdikio raida buvo vertinama pagal AKMRS kriterijus, skiriant balą už kiekvieną atliktą veiksmą ir susumuojant bendrą rezultatą.

Statistinė duomenų analizė. Atlikto tyrimo gautiems duomenims apdoroti buvo naudojama Microsoft Excel 2016 programa ir statistinès analizès sistema $R \times 64$ 3.5.1. Statistinès duomenų analizès metu buvo apskaičiuotos įvairių rodiklių skaitinès charakteristikos. Tai imties vidurkis, mediana, minimali ir maksimali reikšmé, standartinis nuokrypis (SN), standartinè paklaida (SP). Duomenu normalumas buvo nustatomas Shapiro'o-Wilk'o testu, nagrinėjami duomenys atitiko normalumo sąlygas, todėl kintamųų vidutinių reikšmių lygybei vertinti buvo naudojamas parametrinis $t$ kriterijus, o tiesinès priklausomybès tarp kintamuju buvo vertinamos skaičiuojant Pearson'o koreliacijos koeficientus. Dviejų rezultatų atitikčiai vertinti buvo naudojamas Kappa koeficientas. Duomenų reikšmingumo lygmuo $\alpha=0,05$.

\section{TYRIMO REZULTATAI}

Bendrieji duomenys. Anketineje apklausoje dalyvavo 41 motina, kuriu amžiaus vidurkis buvo $30,1 \pm 5,81 \mathrm{~m}$. Jauniausia motina buvo $19 \mathrm{~m}$., vyriausia -

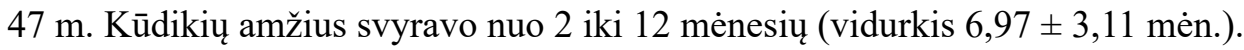

Vidinè darna. Apklausos metu buvo nustatyta, kad motinų vidinès darnos (VD) vidurkis buvo $47,1 \pm 7,05$ balo (žemiausias balas -26 , aukščiausias -60 ). Motinoms, patiriančioms stiprų stresą, vidinès darnos balų vidurkis $(44,9 \pm 7,89$ balo) buvo žemesnis $(\mathrm{p}<0,05)$, lyginant su motinomis, kurios stipraus streso nepatiria $(49,9 \pm 4,61$ balo $)$.

Kasdieniai rūpesčiai. Vertinant tiriamų motinų streso lygị „Kasdienių rūpesčių" skale nustatyta, kad streso lygio vidurkis sieké 52,4 $\pm 12,9$ balo (mažiausią stresą patiriančių tiriamujų balas buvo 26 , stipriausią - 79 balai). Nagrinejjant kitus veiksnius, galinčius turèti įtakos motinų vidinei darnai (tokius kaip vaikų skaičius šeimoje, komplikacijos gimdymo metu, nëštumo nutraukimai praeityje, gimdymo būdas, motinų išsilavinimas, šeiminè padètis, gyvenamoji vieta), reikšmingų skirtumų nenustatyta.

Motinos darna su kūdikiu. Apklausos metu buvo nustatyta, kad motinų darnos su kūdikiu vidurkis buvo $54,4 \pm 6,27$ balo (žemiausias balas - 32, aukščiausias - 64). Nustatyta, kad darnos su kūdikiu mažiausias ir aukščiausias balas bei 


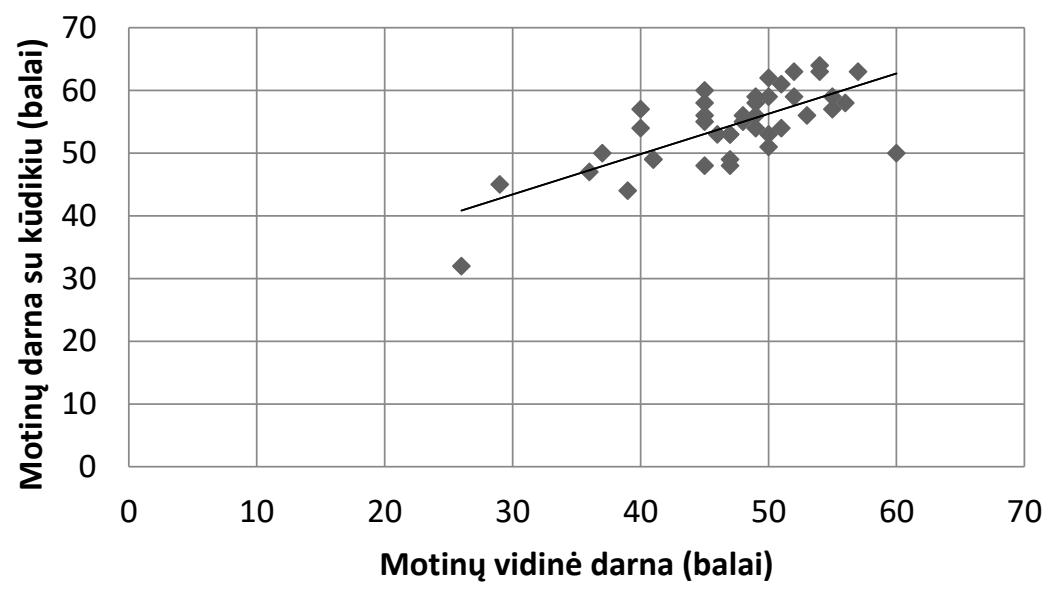

1 pav. Motinų vidinės darnos ir darnos su kūdikiu sąsajos

vidurkis yra aukštesni, lyginant su motinų vidine darna. Taip pat 40 iš 41 apklausoje dalyvavusių motinų savo vidinę darną ịvertino žemiau, nei jų darną su kūdikiu. Atliekant duomenų analizę buvo nustatyta, kad motinų, turinčių žemą darnos su kūdikiu balą, vidinès darnos vidurkis buvo reikšmingai $(\mathrm{p}=0,003)$ mažesnis $(43,6 \pm 8,02$ balo) nei tų, kurių darna su kūdikiu buvo aukšta $(50,1 \pm 4,34$ balo).

Motinos, pasižyminčios aukšta vidine darna, turèjo ir aukštą darną su kūdikiu $(\mathrm{r}=0,72)(1 \mathrm{pav}$.$) .$

Kūdikių motorinė raida. Pildant apklausos anketą tiriamosios turèjo atsakyti, ar, jų manymu, kūdikių motoriniai ịgūdžiai atitinka jo amžiui būdingus ịgūdžius ir pagrịsti savo atsakymą. Trisdešimt viena motina (76\%) atsakè, kad jos kūdikio raida neatsilieka nuo normos. Tuo tarpu dešimt (24\%) pažymėjo, kad atsilieka.

Nustatyta, kad dvidešimt šešių (63\%) kūdikių, kurių motorinè raida, naudojant AKMR skalę, sieke 50 procentilių ir daugiau, t. y. nevèlavo, tačiau penkiolikos (37\%) kūdikių motorinè raida buvo ịvertinta žemiau 50 procentilès. Kūdikių subjektyvaus vertinimo, kuri atliko jų mamos, bei gautų AKMRS balų rodiklio palyginimas pavaizduotas 2 paveiksle. Dviejų motorinès raidos įvertinimų ridiklių atitikčiai nustatyti buvo naudojamas Kappa koeficientas, kuris palygina faktinị sutapimų dažnị su tikètinu sutapimų dažniu. Tyrimo rezultatai parodè, kad kūdikiụ subjektyvaus vertinimo bei AKMR skalès rodiklio sutapimas yra pakankamas $(\boldsymbol{\kappa}=$ 0,42 ), todèl galima teigti, kad didžiosios daugumos apklausoje dalyvavusių motinų subjektyvus kūdikio motorinès raidos vertinimas sutapo su AKMRS vertinimu.

Kūdikių motorinès raidos vertinimo duomenys buvo analizuojami ir lyginami tarp kūdikių, kurių motinų vidinė darna yra aukšta (t. y. $>=55)$, ir tų, kurių vidinès darnos lygis buvo žemas ( $<55$ balai). Lyginant motorinès raidos balų rodiklį 


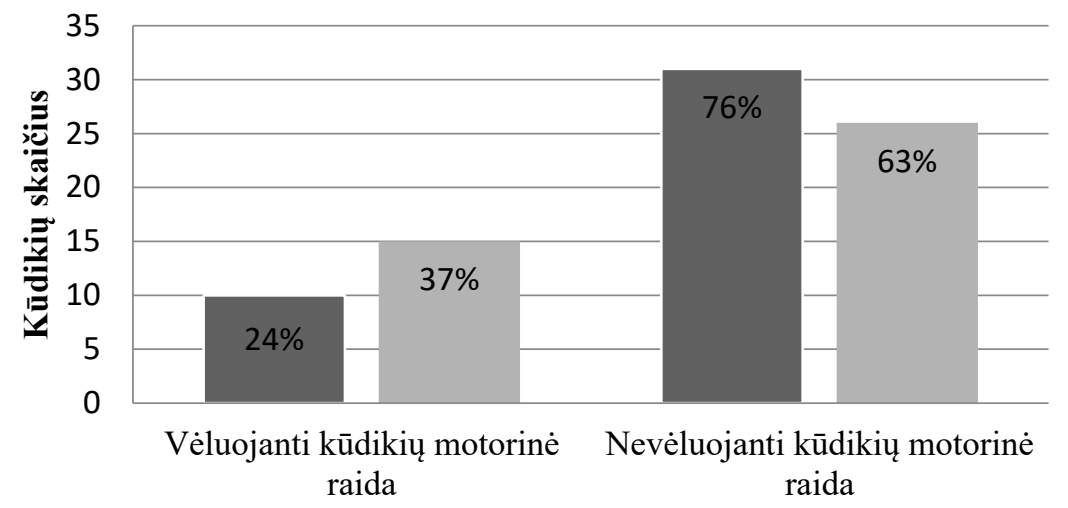

- Subjektyvus kūdikių motorinès raidos vertinimas $\square$ AKMRS balai

2 pav. Kūdikių subjektyvaus vertinimo ir motorinès raidos pagal AKMRS sąsajos

tarp kūdikių, kurių motinų vidinès darnos lygis buvo žemas, ir tarp tų, kurių vidinės darnos lygis buvo aukštas, statistiškai reikšmingo skirtumo nebuvo pastebėta. Lyginant vidinès darnos balų vidurkị tarp motinų, kurios nurodè, kad jų kūdikių motorinè raida vèluoja, ir tarp tų motinų, kurios nurodè, kad nevèluoja, taip pat nebuvo pastebėta statistiškai reikšmingo skirtumo. Motinų subjektyvus jų kūdikių motorinès raidos vertinimas nepriklausè nuo jų vidinès darnos lygio.

\section{REZULTATŲ APTARIMAS}

Šio tyrimo tikslas buvo nustatyti motinų vidinės darnos lygi, motinų darnos su kūdikiu lygị ir išanalizuoti sąsajas su kūdikių motorinès raidos lygiu. Yra žinoma, kad motinos psichinė sveikata yra svarbus veiksnys, lemiantis kūdikio socialinį, fiziologinį bei emocinị vystymąsi. Psichologinès problemos, tokios kaip motinos depresija ar nerimo sutrikimai jau ilgą laiką yra tiriami ir moksliniuose šaltiniuose aprašomi kaip rizikos veiksniai, galintys paveikti kūdikio motorinę raidą pirmaisiais gyvenimo metais (Gete et al., 2019).

Analizuojant anketavimo metu gautus duomenis buvo siekiama nustatyti, nuo kokių veiksnių gali priklausyti motinų vidinės darnos jausmas. Tyrimo rezultatai parode, kad motinos vidinè darna statistiškai reikšmingai siejosi su motinų patiriamu stresu. Panašų rezultatą aprašè ir I. Hildingsson'as savo straipsnyje (2017), pastebejjęs, kad stresas neigiamai koreliuoja su vidine darna. Pasak straipsnio autorių, vidinès darnos nustatymas ankstyvojo nèštumo metu gali padėti motinoms išvengti stipraus streso gimus kūdikiui. M. Huhtala su bendraautoriais (2014) priè- 
jo prie išvados, kad motinos depresijos simptomai ir abiejų tėvų patiriamas stresas kelia ikimokyklinio amžiaus vaikų sulètėjusios socialinės bei elgesio raidos riziką, tuo tarpu motinos aukštas vidinès darnos jausmas tą riziką mažina.

Vertinant tyrimo duomenis, buvo nustatytas stiprus koreliacinis ryšys tarp motinų vidinès darnos ir motinų darnos su kūdikiu. Taip pat analizuojant duomenis pastebèta, kad motinos darna su kūdikiu buvo stipresnè, negu pačios motinos vidinè darna. Tokia koreliacija nustatyta ir D. Juodienès (2007) atliktame tyrime. Pasak jos, vidinès darnos jausmas siejamas su išsilavinimu - aukštesnio išsilavinimo siekiančios moterys pasižymi smalsumu, stengiasi surasti atsakymus i kylančius klausimus, moka atrasti patikimos informacijos, ir tai gali turèti itakos motinos požiūriui ị kūdikị, jo poreikių supratimui ir tenkinimui. Visgi analizuojant mūsų tyrimo rezultatus statistiškai reikšmingos sąsajos tarp išsilavinimo ir motinų vidinès darnos neaptikta. D. Juodienès (2007) tyrimo rezultatai parodè, kad motinų vidinė darna reikšmingai priklausė nuo to, ar kūdikis buvo planuotas. Taip pat ji nurodo, kad gimdymo eiga yra reikšmingas veiksnys, susijęs su motinos vidine darna. Tačiau mūsų tyrimo rezultatai rodo, kad tarp apklausoje dalyvavusių motinų vidinès darnos jausmo ir anksčiau paminètų veiksnių statistiškai reikšmingų sąsajų nebuvo.

S. Ferguson (2016) savo straipsnyje pabrèžè, kad nèštumo metu turi būti skiriamas ypatingas dėmesys moterų vidinės darnos jausmo stiprinimui, nes jos atlikto tyrimo rezultatai parodè, kad moterims, turinčioms stiprią vidinę darną, gimdymo metu rečiau atliekamas cezario pjūvis, lyginant su moterimis, kurių vidinès darnos jausmas yra žemas. Mes, tyrimo metu lygindami vidinès darnos balų sumą tarp tų motinų, kurioms buvo atliktas cezario pjūvis, ir tų, kurioms nebuvo, statistiškai reikšmingo skirtumo nenustatėme. Nebuvo reikšmingo skirtumo tarp motinų, turèjusių komplikacijas gimdymo metu, ir komplikacijų nuturejjusių vidinės darnos balų, o S. Ferguson su bendraautoriais (2016) tyrime prièjo prie išvados, kad komplikacijos gimdymo metu bei nepasitenkinimas gimdymu mažina vidinės darnos jausmą.

Motinos žinios ir mokejimas tinkamai ịvertinti savo kūdikio raidą yra labai svarbūs auginant ir ugdant kūdikị. K. Y. Huang'as su bendraautoriais (2005) teigia, kad motinos, turinčios daugiau žinių apie kūdikio raidą ir mokančios tinkamai ịvertinti kūdikio raidos etapus, linkusios daugiau skirti dèmesio ir bendrauti su kūdikiu, todèl tokių kūdikių kognityvinè raida būna geresnè, lyginant su kūdikiais, kurių motinos tokių žinių turi nepakankamai. Mūsų tyrime buvo lyginami motorinès raidos balai (pagal AKMRS) tarp kūdikių, kurių motinų manymu raida atsilieka nuo normos, ir tų, kurių motinų manymu motorinè raida atitinka chronologini amžių. Gauti rezultatai parodè, kad daugumos motinų subjektyvus kūdikių motorinès raidos ịvertinimas sutapo su gautais AKMRS balais. 
Prieš atlikdami tyrimą tikèjomès, kad kūdikių motorinès raidos subjektyvus vertinimas priklausys nuo jų motinų vidinès darnos lygio, tačiau tai nepasitvirtino. Silpnas vidinès darnos jausmas yra siejamas su stresu ir vadinamas depresijos prediktoriumi (Kovi et al., 2017). Todèl negalima atmesti galimybès, kad vidinès darnos jausmas, turèdamas stiprią įtaką motinų psichologinei sveikatai, gali paveikti ir kūdikio vystymąsi. Ateityje reikètų praplèsti tyrimus su didesne motinų imtimi ir palyginti, ar jaunesniojo amžiaus motinos su mažesne gyvenimiška patirtimi turi vienodą vidinès darnos ir darnos su kūdikiu lygị.

\section{IŠVADOS}

Motinų vidinės darnos balų vidurkis siekè žemą vidinès darnos lygị. Motinų vidinei darnai laikotarpiu po gimdymo statistiškai reikšmingą itaką turejjo tik stresas. Motinų darna su kūdikiu buvo aukštesnè nei motinų vidinè darna. Nors dauguma apklaustų motinų ịvertino savo kūdikio raidą kaip normalią, 24\% respondenčiu pažymėjo, kad jų kūdikių motorinè raida atsilieka nuo normos. Daugumos motinų subjektyvus kūdikio motorinès raidos įvertinimas sutapo su motorinès raidos vertinimu pagal Alberta motorinès raidos skalę, be to, motinų vidinè darna neturéjo reikšmingų sąsajų su subjektyviu kūdikių motorinès raidos vertinimu.

\section{Finansavimas: nėra. \\ Interesų atskleidimas: nèra.}

\section{LITERATŪRA}

Bauer, G. F., Roy, M., Bakibinga, P. et al. (2020). Future directions for the concept of salutogenesis: A position article. Health Promotion International, 35 (2), 187-195.

Crnic, K. A., Greenberg, M. T. (1990). Minor parenting stresses with young children. Child Development, 61, $1628-1637$.

del-Pino-Casado, R., Espinosa-Medina, A., López-Martínez, C., Orgeta, V. (2019). Sense of coherence, burden and mental health in caregiving: A systematic review and meta-analysis. Journal of Affective Disorders, 242, $14-21$.

Eriksson, M., Lindström, B. (2005). Validity of Antonovsky's sense of coherence scale: A systematic review. Journal of Epidemiology \& Community Health, 59 (6), 460-466.

Ferguson, S., Browne, J., Taylor, J., Davis, D. (2016). Sense of coherence and women' s birthing outcomes: A longitudinal survey. Midwifery, 34, 158-165.

Gete, S., Calderon-Margalit, R., Grotto, I., Ornoy, A. (2019). A comparison of the effects of maternal anxiety and depression on child development. European Journal of Public Health, 29 (Suppl. 4), ckz185-275.

Hildingsson, I. (2017). Sense of coherence in pregnant and new mothers - A longitudinal study of a national cohort of Swedish speaking women. Sexual \& Reproductive Healthcare, 11, 91-96.

Huang, K. Y., Caughy, M. O. B., Genevro, J. L., Miller, T. L. (2005). Maternal knowledge of child development and quality of parenting among White, African-American and Hispanic mothers. Journal of Applied Developmental Psychology, 26 (2), 149-170.

Huhtala, M., Korja, R., Lehtonen, L. et al. (2014). Associations between parental psychological well-being and socio-emotional development in 5-year-old preterm children. Early Human Development, 90 (3), $119-124$. 
Juodienè, D. (2007). Motinos vidinès darnos ir motinos darnos su kūdikiu sąsajos: magistro diplominis darbas. Kaunas: Lietuvos sveikatos mokslu universitetas.

Kerstis, B., Engström, G., Edlund, B., Aarts, C. (2013). Association between mothers' and fathers' depressive symptoms, sense of coherence and perception of their child's temperament in early parenthood in Sweden. Scandinavian Journal of Public Health, 41 (3), 233-239.

Kövi, Z., Odler, V., Gacsályi, S. et al. (2017). Sense of coherence as a mediator between personality and depression. Personality and Individual Differences, 114, 119-124.

Markūnienè, E. (2003). Medicininiai, psichologiniai kūdikiu žindymo veiksniai: daktaro disertacija. Kaunas: KMU.

Mittelmark, M. B., Sagy, S., Eriksson, M. et al. (2017). The Handbook of Salutogenesis. Springer Nature.

Piper, M. C., Pinnell, L. E., Darrah, J., Maguire, T., Byrne, P. J. (1992). Construction and validation of the Alberta Infant Motor Scale (AIMS). Canadian Journal of Public Health = Revue Canadienne De Sante Publique, 83, S46-50.

Radzevič, V., Veniūtè-Jakubauskienė, M., Raistenskis, J., Stukas, R. (2019). Psichosocialinių veiksnių ịtaka motinos depresiškumui laikotarpiu po gimdymo ir vaiko raidai pirmaisiais gyvenimo metais. Visuomenes sveikata, $85,15-21$.

Sekizuka, N., Nakamura, H., Shimada, K. et al. (2006). Relationship between sense of coherence in final stage of pregnancy and postpartum stress reactions. Environmental Health and Preventive Medicine, 11 (4), 199-205.

Soares, H., Barbieri-Figueiredo, M., Pereira, S., Silva, M., Fuertes, M. (2018). Parents attending to nurse visits and birth age contribute to infant development: A study about the determinants of infant development. Early Human Development, 122, 15-21.

Stewart, D. E., Vigod, S. N. (2019). Postpartum depression: Pathophysiology, treatment, and emerging therapeutics. Annual Review of Medicine, 70, 183-196.

\title{
RELATIONSHIP BETWEEN SUBJECTIVE EVALUATION OF MATERNAL SENSE OF COHERENCE AND INFANT MOTOR DEVELOPMENT
}

\author{
Viktorija Sytnikova ${ }^{1}$, Veslava Radzevič ${ }^{1,2}$, Lina Budriene $\dot{e}^{1,2}$, \\ Juozas Raistenskis ${ }^{1,2}$, Vilma Dudoniené ${ }^{3}$ \\ Vilnius University ${ }^{l}$ \\ Children's Hospital, Santara Clinic Branch of Vilnius University Hospital ${ }^{2}$ \\ Lithuanian Sports University ${ }^{3}$
}

\section{ABSTRACT}

Background. Depressive mothers are less interested in the development of the infant and therefore have less knowledge about infant's development. It can affect mother's attitude towards the infant. Many sources state that a poor sense of coherence (SOC) is associated with increased stress, also SOC is one of the risk factors for depression. So, there is possibility that mother's SOC can affect motor development of infant.

Aim. The aim of the study was to evaluate relationship between subjective evaluation of maternal sense of coherence and infant motor development. 
Methods. Forty-one mothers were surveyed by five questionnaires: sociodemographic block, Sense of Coherence Scale, Coherence with a baby scale, Daily hassles scale, and Alberta Infant Motor Scale, which was modified into a questionnaire to allow mothers independently evaluate their baby's motor development.

Results. According to the study, mothers under severe stress had a statistically significant lower mean score of SOC $(44.9 \pm 7.89)$ compared to mothers who did not experience severe stress $(49.9 \pm 4.61)(\mathrm{p}=0.01)$. A strong correlation was observed between maternal sense of coherence and coherence with the baby $(r=$ $0.72 ; \mathrm{p}=0.003)$. Subjective evaluation of infants' motor development done by their mothers did not depend on the Sense of Coherence $(r=0.13 ; p=0.14)$. There was no significant relationship between motor development of infants and maternal Sense of Coherence $(r=0.03 ; p=0.40)$.

Conclusion. Mothers with a strong sense of coherence also had strong coherence with the infant. Maternal Sense of Coherence had no statistically significant relationship with the baby's motor development.

Keywords: sense of coherence, mother's coherence with infant, postpartum depression, motor development.

Gautas 20200904

Priimtas 20201105 